\title{
A Systematic Literature Review of Success Factors and Barriers of Agile Software Development
}

\author{
Shahbaz Ahmed Khan Ghayyur ${ }^{1}$, Salman Ahmed ${ }^{2}$, \\ Mukhtar $\mathrm{Ali}^{3}$, Abdul Razzaq ${ }^{5}$, Naveed Ahmed ${ }^{6}$ \\ Department of Computer Sciences and Software \\ Engineering, International Islamic University, \\ Islamabad, Pakistan
}

\author{
Adnan Naseem ${ }^{4}$ \\ Department of Computer Sciences, \\ COMSATS Institute of Information Technology, \\ Islamabad, Pakistan
}

\begin{abstract}
Motivator and demotivator plays an important role in software industry. It encompasses software performance and productivity which are necessary for projects of Agile software development (ASD). Existing studies comprise of motivators and demotivators of ASD, which exist in dispersed form. That is why there is a need of a detailed systematic literature review to review the factors and sub-factors effecting motivators and demotivators in ASD. A comprehensive review is executed to gather the critical success factors of motivator and demotivator of Agile software development. Thus, the ongoing study classifies motivator and demotivator factors into four classes, i.e., people, organization, technical and process. However, sub-classification is also executed to clarify more of the motivators of agile. Along with this, motivator and demotivator of scrum process is also categorized to overview a clear vision.
\end{abstract}

Keywords-Agile methods; systematic literature review; motivator; demotivator; success factors; barriers; scrum; ASD

\section{INTRODUCTION}

\section{A. Motivation}

Agile Software development (ASD) provides an iterative way to make effective and efficient software development. It contains set of rules and principle with self-organizing teams. In Software development, motivator plays an important role to enhance the personal and technical skills. Motivator is a critical factor in achieving project scope by clarifying the business goals. McHugh et al. [1] has analysed the effect of motivator and demotivator on core three agile practices. Qualitative analysis has been performed to fulfil this purpose. This systemic literature review will gather the existing knowledge of motivator and demotivator.

In ASD, due to its iterative nature ratio of failure projects are less than SDLC but when it comes to individual personal and technical skills, there is need of motivator and demotivator factors effecting ASD. These motivators and demotivators works as an umbrella activities throughout the project that's why there is need to control the demotivator factors to increase the motivator factors afterward. The literature depicts that effective management is the backbone of project success and can reduce the failure ratio up to $70 \%$ of their total cost. ASD has multiple methods which follow the one agile manifesto for continuous development throughout the life cycle.

\section{B. Need of Systematic Literature Review}

From the previous 10 to 15 years, ASD showed great boom in software industry and it bypass the existing SDLC technique due to its more success stories that's why there is a revival of agile industry all over the world and sooner or later it will become the best adopted technique to its flexible environment. Existing literature depicts, that is, it lacks a detailed systematic literature of ASD and there is a need of systematic literature review to cover this gap. This study encounters the existing studies on motivator and demotivator factor to make the detailed list. The data is present in dispersed format and needs to gather for systematic literature review.

This SLR will help in managing the self-organizing teams by providing them confidence and support for help in work done. Cockburn and Highsmith [2] proposed rewards and incentives as most common motivating factor. The literature encompasses the people factor in which stress is a demotivating factor. ASD works on software development that yields success as well as stakeholder satisfaction.

Motivator and demotivator factors are challenging work that they need to be identified and must be noted. Secondly, our main contribution is to categorize the motivator and demotivator factor into people, technical and organization background. For this purpose, we have done a detail study of relevant papers of motivators and demotivators and classified, respectively.

The structure of remaining paper is: Section 2 describes the Literature Review. Section 3 explains methodology of the research. Sections 4 to 7 illustrate the output and findings, classification and quality Assessment. Section 8 encompasses discussion, then finally conclusion in Section 9.

\section{LITERATURE REVIEW}

The current section emphasises on the studies which are very close to the research of this study.

Several factors of motivators in ASD are focused in [3]. They propose model of motivation of software Engineering (MOCC) in which different factors of software engineering is been identified. To proof his domain study they have done factors with respect to technical aspects. The primary fellow of agile give brief view of how agile can be implemented against 
traditional software development [2]. Akhtar et al. [4] find the scrum critical factors in native software industry. As a result, the authors provide different recommendations to increase the productivity of software. Author in [5] has provided scrum adoption and implementation challenges in Pakistan due to its novice adoption in this area. In another study, [6] has focused on success factors of ASD. For this purpose they do a detail study of agile methods. The important contribution of Wagener is the division of the extracted elements in four classes, i.e., process, organizational, technical and people classes. An empirical study along with SLR has been conducted by [7] have on different agile projects. Regression analysis is used to evaluate result of 109 agile teams. Baddoo and Hall [8] describe the rewarding as most motivating factor. Another study on motivators and demotivators were conducted on software industry of Pakistan by [9]. To evaluate the literature regarding motivator and demotivator a systematic literature review is done. They propose an extension in hosted 5D's model by adding culture in it.

\section{RESEARCH METHOD}

\section{A. Systematic Literature Review}

It comprises of snowballing process for the assessment of relevant literature [10]. An evaluation process is used to accomplish the review. After that the output will describe the detailed list of motivators and demotivators, and classification and sub-classification of motivators and demotivators has been done.

\section{B. Planning of Mapping}

Current systematic literature review is done for the evaluation of the relevant data comprising motivator and demotivator of agile software development. The data exist in dispersed form and there is a need of complete literature review to collect all such distributed data.

\section{Research Questions}

There are three research questions of current research as shown in Table I.

\section{Search Strings}

The search strings used for the extraction of relevant studies are:

(((\{MOTIVATOR\} OR \{MOTIVATORS $\})$ OR

\{DEMOTIVATOR\} OR \{DEMOTIVATOR\} OR

\{DEMOTIVATOR\} OR \{DEMOTIVATORS\}) OR

\{SUCCESS\}) OR \{BARRIER\}) OR \{AGILE\} OR \{AGILE

SOFTWARE DEVELOPMENT\} OR $\{A S D\}$

\section{E. Databases}

We have targeted every search engine and find out maximum no research papers. Mostly papers are extracted by IEEE, ACM and Springer. Paper must publish in between 2000 to 2018 .

\section{F. Factor Mining}

In order to elaborate the maximum number of motivators and demotivators factors, a selection procedure described in Table II is followed to find relevant papers according to string.

\section{G. Selection of Primary Study}

To select any paper title, abstract and conclusion has been explored. Those papers that have ambiguity and unclear objectives have been discarded.

\section{1) Inclusion Criteria}

Following points are examined to inclusion criteria:

- Must be published in Conference or Journal.

- Medium of language is English.

- Studies can solid accessible link.

- Paper must publish after 2000.

2) Exclusion Criteria

The exclusion criterion comprises of following points:

- “Tutorials", “slides", “editorials", “posters", keynotes and other non-peer reviews are excluded.

- Peer reviewed, but blog and books are not acceptable.

- Non-English language publications.

- All the studies which are unable to E-access.

\section{H. Performing SLR}

All the studies which have a solid background related to agile is been selected as shown in Table III. Conference and Journal papers are selected to give solid background. Selected primary studies are 39. However, the following papers are extracted which are most suitable against our research string.

\section{Quality Assessment}

Research papers having score in between 1 and 3 are been selected and those who have less than 1 are neglected (Table IV).

\section{J. Selected Paper Description}

All the research papers selected after applying the quality assessment criteria are summarized critically in Table V.

TABLE I. QUESTIONS OF THE RESEARCH

\begin{tabular}{|c|c|c|}
\hline S. No. & RQs & Motivation \\
\hline RQ.1 & What are the motivator and demotivator factors in ASD? & It intended to provide a detailed list of motivators and demotivators of agile. \\
\hline $\mathrm{RQ} .2$ & How could motivators and demotivators be mapped with common factors? & $\begin{array}{l}\text { RQ2 aims to deliver the mapping of motivator factor into procedural, stakeholders, } \\
\text { and firm's factors. }\end{array}$ \\
\hline RQ.3 & How could motivators and demotivators be sub-factorization? & RQ3 emphases on the sub-factorization. \\
\hline
\end{tabular}


TABLE II. DOCUMENT SELECTION PROCEDURE

\begin{tabular}{|l|l|}
\hline Step 1.1 & Read all the title and abstract and extract relevant paper. \\
\hline Step 1.2 & Intro and conclusion based selection. \\
\hline Step 1.3 & Thoroughly read all the papers to remove any duplication in studies \\
\hline Step 1.4 & Quality Assessment form is made according to compile better result. \\
\hline
\end{tabular}

TABLE III. FILTRATION OF PAPERS

\begin{tabular}{|l|l|l|l|l|l|}
\hline Databases & Papers & $\begin{array}{l}\text { Title } \\
\text { Filtration }\end{array}$ & $\begin{array}{l}\text { Abstract } \\
\text { Filtration }\end{array}$ & Selected & Ref. \\
\hline IEEE Xplore & 915 & 54 & 24 & 11 & {$[11][12][13][14][15][16][17][18][19][20][21]$} \\
\hline ACM Digital Library & 37 & 17 & 10 & 03 & {$[22][23][24]$} \\
\hline Science Direct & 36 & 15 & 07 & 03 & {$[25][26][27]$} \\
\hline Research Gate & 32 & 25 & 10 & 06 & {$[28][29][30][31][32][33]$} \\
\hline Scopus & 07 & 05 & 02 & 03 & {$[7][34][35]$} \\
\hline Springer & 97 & 51 & 11 & 04 & {$[36][37][38][39]$} \\
\hline Google Scholar & 300 & 90 & 35 & 05 & {$[40][41][42][1][43]$} \\
\hline Others & 223 & 60 & 30 & 03 & {$[44][45][46]$} \\
\hline Total & $\mathbf{2 4 2 2}$ & $\mathbf{3 8 1}$ & $\mathbf{2 2 6}$ & $\mathbf{3 8}$ & \\
\hline
\end{tabular}

TABLE IV. QUALITY ASSESSMENT OF PAPERS

\begin{tabular}{|c|c|c|c|c|c|}
\hline Sr. No & Paper & RQ \# 1 & RQ \# 2 & RQ \#3 & Total \\
\hline 1 & [47] & 0.5 & 1 & 0 & 1.5 \\
\hline 2 & [48] & 0.5 & 0.5 & 0 & 1 \\
\hline 3 & [49] & 0.5 & 0 & 0 & 0.5 \\
\hline 4 & [15] & 1 & 0.5 & 0 & 1.5 \\
\hline 5 & [46] & 0.5 & 0.5 & 0.5 & 1.5 \\
\hline 6 & [50] & 0.5 & 1 & 0.5 & 2 \\
\hline 7 & [51] & 0 & 0.5 & 0 & 0.5 \\
\hline 8 & [52] & 0.5 & 0 & 0 & 0.5 \\
\hline 9 & [16] & 1 & 0.5 & 0 & 1.5 \\
\hline 10 & [53] & 0 & 0.5 & 0.5 & 1 \\
\hline 11 & [54] & 1 & 1 & 0.5 & 2.5 \\
\hline 12 & [17] & 1 & 1 & 0.5 & 2.5 \\
\hline 13 & [55] & 1 & 0.5 & 1 & 2.5 \\
\hline 14 & [22] & 1 & 0.5 & 0.5 & 2.5 \\
\hline 15 & [23] & 1 & 1 & 0 & 2 \\
\hline 16 & [56] & 1 & 0 & 0 & 1 \\
\hline 17 & [57] & 1 & 1 & 0.5 & 2.5 \\
\hline 18 & [58] & 1 & 1 & 0.5 & 2.5 \\
\hline 19 & [29] & 1 & 0.5 & 1 & 2.5 \\
\hline 20 & [59] & 0.5 & 0.5 & 0 & 1 \\
\hline 21 & [60] & 1 & 1 & 1 & 3 \\
\hline 22 & [61] & 0.5 & 0.5 & 0 & 1 \\
\hline 23 & {$[40]$} & 1 & 1 & 0.5 & 2.5 \\
\hline 24 & [62] & 1 & 1 & 0.5 & 2.5 \\
\hline 25 & {$[63]$} & 1 & 0.5 & 0 & 1.5 \\
\hline 26 & [14] & 0.5 & 0.5 & 0.5 & 1.5 \\
\hline 27 & {$[1]$} & 1 & 0.5 & 0 & 1.5 \\
\hline 28 & [64] & 1 & 0.5 & 1 & 2.5 \\
\hline 29 & [37] & 1 & 1 & 0.5 & 2.5 \\
\hline 30 & [65] & 1 & 0.5 & 0 & 1.5 \\
\hline 31 & [33] & 1 & 1 & 1 & 3 \\
\hline 32 & [66] & 0.5 & 0 & 0 & $\begin{array}{l}0.5 \\
\end{array}$ \\
\hline 33 & [67] & 1 & 0 & 0 & 1 \\
\hline 34 & {$[68]$} & 0.5 & 0.5 & 0 & 1 \\
\hline 35 & [69] & 1 & 0 & 0 & 1 \\
\hline 36 & [7] & 1 & 1 & 0.5 & 2.5 \\
\hline 37 & [6] & 1 & 0.5 & 0 & 1.5 \\
\hline 38 & [2] & 0.5 & 0.5 & 0 & 1 \\
\hline 39 & [36] & 1 & 0.5 & 0.5 & 2 \\
\hline 40 & {$[70]$} & 0.5 & 0 & 0 & 0.5 \\
\hline 41 & [71] & 1 & 1 & 0.5 & 2.5 \\
\hline 42 & [72] & 0.5 & 0 & 0 & 0.5 \\
\hline 43 & [17] & 1 & 0.5 & 0.5 & 2 \\
\hline 44 & [39] & 1 & 1 & 0.5 & 2.5 \\
\hline
\end{tabular}




\begin{tabular}{|l|l|l|l|l|l|}
\hline 45 & {$[73]$} & 0.5 & 0 & 0 & $\mathbf{0 . 5}$ \\
\hline 46 & {$[74]$} & 0.5 & 0.5 & 0 & $\mathbf{1}$ \\
\hline 47 & {$[75]$} & 0.5 & 0 & 0 & $\mathbf{0 . 5}$ \\
\hline 48 & {$[45]$} & 1 & 1 & 0.5 & $\mathbf{2 . 5}$ \\
\hline 49 & {$[20]$} & 1 & 1 & 0.5 & $\mathbf{2 . 5}$ \\
\hline 50 & {$[57]$} & 1 & 0.5 & 0.5 & $\mathbf{2}$ \\
\hline 51 & {$[76]$} & 1 & 0.5 & 0 & $\mathbf{1 . 5}$ \\
\hline 52 & {$[77]$} & 1 & 1 & 0 & $\mathbf{2}$ \\
\hline 53 & {$[78]$} & 1 & 0.5 & 0 & $\mathbf{1 . 5}$ \\
\hline 54 & {$[38]$} & 1 & 1 & 0.5 & 0.5 \\
\hline 55 & {$[26]$} & 1 & 1 & 1 & $\mathbf{2 . 5}$ \\
\hline 56 & {$[43]$} & 1 & & $\mathbf{3}$ & \\
\hline
\end{tabular}

TABLE V. DETAIL DESCRIPTION OF SELECTED PAPERS

\begin{tabular}{|c|c|c|c|c|c|c|c|}
\hline Sr. No & $\begin{array}{l}\text { Type: } \\
\text { Conference/ } \\
\text { Journal }\end{array}$ & $\begin{array}{l}\text { Technique/ } \\
\text { Empirical / } \\
\text { Survey }\end{array}$ & Objectives & Results & Contribution & Limitation & Ref. \\
\hline 1 & $\begin{array}{l}\text { (CHASE) } 2013 \\
\text { 6th International } \\
\text { Workshop }\end{array}$ & $\begin{array}{l}\text { Empirical } \\
\text { Analysis }\end{array}$ & $\begin{array}{l}\text { To made a model } \\
\text { to minimize } \\
\text { software engineer } \\
\text { workload }\end{array}$ & $\begin{array}{l}\text { Proposed motivation } \\
\text { factors of organization. }\end{array}$ & $\begin{array}{l}\text { Complex interplay } \\
\text { among motivational } \\
\text { factor. }\end{array}$ & $\begin{array}{l}\text { Systematic cross case } \\
\text { analyses of the result is less } \\
\text { reported }\end{array}$ & [47] \\
\hline 2 & $\begin{array}{l}\text { (CHASE), } 2017 \\
\text { 10th International } \\
\text { Workshop }\end{array}$ & $\begin{array}{l}\text { Statistical and } \\
\text { thematic } \\
\text { analysis }\end{array}$ & $\begin{array}{l}\text { To identified three } \\
\text { groups of factors } \\
\text { motivating the } \\
\text { self-assignment: } \\
\text { task-based, } \\
\text { developer-based, } \\
\text { and opinion-based } \\
\text { factors }\end{array}$ & $\begin{array}{l}\text { Majority of the } \\
\text { participants preferred } \\
\text { self-assignment }\end{array}$ & $\begin{array}{l}\text { Precedence to task- } \\
\text { based and developer- } \\
\text { based factors }\end{array}$ & $\begin{array}{l}\text { Developers } \\
\text { may deviate from their } \\
\text { usual practice }\end{array}$ & [15] \\
\hline 3 & $\begin{array}{l}\text { (APSEC) } 2012 \\
19^{\text {th }} \\
\text { International } \\
\text { conference }\end{array}$ & $\begin{array}{l}\text { Regression } \\
\text { model }\end{array}$ & $\begin{array}{l}\text { To check the } \\
\text { relationship } \\
\text { between the } \\
\text { software } \\
\text { Project team } \\
\text { features and team } \\
\text { performance }\end{array}$ & $\begin{array}{l}\text { Administration should } \\
\text { pay more consideration } \\
\text { Team encouragement } \\
\text { within the project teams } \\
\text { so that an improved } \\
\text { strategy } \\
\text { Presentation can be } \\
\text { accomplished }\end{array}$ & $\begin{array}{l}\text { The results } \\
\text { demonstrated the } \\
\text { association among } \\
\text { project team features } \\
\text { and presentation } \\
\text { could be affected } \\
\text { with players' } \\
\text { inspiration. }\end{array}$ & $\begin{array}{l}\text { The association among } \\
\text { software } \\
\text { project team features and } \\
\text { its presentation is still to } \\
\text { gauge. }\end{array}$ & [46] \\
\hline 4 & $\begin{array}{l}\text { (ESEM) } \\
2011\end{array}$ & $\begin{array}{l}\text { Qualitative } \\
\text { research }\end{array}$ & $\begin{array}{l}\text { To Update } \\
\text { Motivators factors } \\
\text { of software } \\
\text { Engineers }\end{array}$ & $\begin{array}{l}\text { About the information } \\
\text { It's good to work and } \\
\text { going } \\
\text { 'Man' is important, but } \\
\text { this 'obstacle' is really } \\
\text { soft } \\
\text { The power of software } \\
\text { engineers }\end{array}$ & $\begin{array}{l}\text { 'Work' (personal } \\
\text { interest) } \\
\text { You need a fix } \\
\text { Screw out. }\end{array}$ & $\begin{array}{l}\text { Focus on working to work } \\
\text { Research on Psychological } \\
\text { and Social Studies }\end{array}$ & [50] \\
\hline 5 & $\begin{array}{l}(\mathrm{CESI}) \\
20175^{\text {th }} \\
\text { IEEE/ ACM }\end{array}$ & $\begin{array}{l}\text { An industry } \\
\text { experiment } \\
\text { with } \\
\text { experienced } \\
\text { programmers at } \\
\text { the Universidad } \\
\text { de las Fuerzas } \\
\text { Armadas ESPE } \\
\text { of Ecuador was } \\
\text { performed }\end{array}$ & $\begin{array}{l}\text { To Identify the } \\
\text { circumstances that } \\
\text { explain why } \\
\text { some } \\
\text { experimental } \\
\text { subjects exhibit } \\
\text { poor or null } \\
\text { participation } \\
\text { during } \\
\text { experimental } \\
\text { sessions. }\end{array}$ & $\begin{array}{l}\text { Several experienced } \\
\text { professionals were } \\
\text { found to live } \\
\text { a two, mixed-factors } \\
\text { reality: old age and } \\
\text { technological lapse. }\end{array}$ & $\begin{array}{l}\text { A high percentage } \\
\text { of older experienced } \\
\text { programmers did not } \\
\text { perform meaningful } \\
\text { work in their task }\end{array}$ & $\begin{array}{l}\text { Further research is required } \\
\text { to better understand this } \\
\text { phenomenon, which has } \\
\text { several interesting } \\
\text { ramifications. }\end{array}$ & [16] \\
\hline 6 & $\begin{array}{l}\text { Proceedings of } \\
\text { EASE (2011) }\end{array}$ & $\begin{array}{l}\text { This is based on } \\
\text { the principles of } \\
\text { specific } \\
\text { guidance } \\
\text { We copied the } \\
\text { initial research } \\
\text { program. }\end{array}$ & $\begin{array}{l}\text { This work has } \\
\text { been updated } \\
2006 \text { encouraged } \\
\text { an encouraging } \\
\text { result } \\
\text { Software } \\
\text { Engineering }\end{array}$ & $\begin{array}{l}\text { Manual search and } \\
\text { automatic search 6,534 } \\
\text { collection } \\
53 \text { papers were selected } \\
\text { for extracting figures } \\
\text { And studying many } \\
\text { solutions to solving } \\
\text { excitement } \\
\text { Despite quantities } \\
\text { scenes and methods }\end{array}$ & $\begin{array}{l}\text { In order to increase } \\
\text { future research, } \\
\text { research should be } \\
\text { more focused on } \\
\text { further deep research }\end{array}$ & $\begin{array}{l}\text { Analyse the relationship } \\
\text { between the motivation and } \\
\text { the results, } \\
\text { To provide more reliable } \\
\text { results. }\end{array}$ & [54] \\
\hline 7 & $\begin{array}{l}\text { SBES } \\
\text { 26th conference } \\
(2012)\end{array}$ & $\begin{array}{l}\text { Qualitative and } \\
\text { Quantitative } \\
\text { analysis }\end{array}$ & $\begin{array}{l}\text { This article } \\
\text { discusses how to } \\
\text { practice XP } \\
\text { Software } \\
\end{array}$ & $\begin{array}{l}\text { Ask for the advice of } \\
\text { five adult } X \text { teams } \\
\text { Consider whether this } \\
\text { feature is the indicator }\end{array}$ & $\begin{array}{l}\text { Got the XP team } \\
\text { There is a proper } \\
\text { process in our } \\
\text { research to support }\end{array}$ & $\begin{array}{l}\text { The XP situation is at odds } \\
\text { with } \\
\text { other motivational needs }\end{array}$ & [79] \\
\hline
\end{tabular}




\begin{tabular}{|c|c|c|c|c|c|c|c|}
\hline & & & $\begin{array}{l}\text { developers' } \\
\text { excitement } \\
\text { requirements. }\end{array}$ & $\begin{array}{l}\text { The XP environment } \\
\text { exists }\end{array}$ & $\begin{array}{l}\text { many operations } \\
\text { One developer needs } \\
\text { to be encouraged } \\
\text { Traditional } \\
\text { Heavyweight } \\
\text { Software } \\
\text { Development } \\
\text { The environment }\end{array}$ & & \\
\hline 8 & $\begin{array}{l}\text { JSA } \\
(2016)\end{array}$ & $\begin{array}{l}\text { Semi-structured } \\
\text { interview was } \\
\text { held four times } \\
\text { Use monthly } \\
\text { rules to analyse } \\
\text { data } \\
\text { Program }\end{array}$ & $\begin{array}{l}\text { To examine } \\
\text { contextualized } \\
\text { and the } \\
\text { interpretation } \\
\text { principle needs to } \\
\text { be explained } \\
\text { Different }\end{array}$ & $\begin{array}{l}\text { We provide connection } \\
\text { statement, } \\
\text { Understanding } \\
\text { Associate and Related } \\
\text { Articles } \\
\text { The main story of the } \\
\text { company's motivation. }\end{array}$ & $\begin{array}{l}\text { The need for learning } \\
\text { and development is } \\
\text { the most powerful } \\
\text { driver } \\
\text { Movement, which } \\
\text { increases the turnout } \\
\text { of turn } \\
\text { Conditions for } \\
\text { generating better } \\
\text { performance for } \\
\text { engineers. }\end{array}$ & $\begin{array}{l}\text { Features of personality as } \\
\text { personalities and } \\
\text { personality } \\
\text { Style, but elements can } \\
\text { appear in future reports. }\end{array}$ & [80] \\
\hline 9 & $\begin{array}{l}\text { CHASE } \\
20147 \text { th } \\
\text { International } \\
\text { Workshop }\end{array}$ & $\begin{array}{l}\text { Statistical and } \\
\text { thematic } \\
\text { analysis }\end{array}$ & $\begin{array}{l}\text { To compare the } \\
\text { team's business- } \\
\text { related results } \\
\text { (productivity and } \\
\text { quality) to two } \\
\text { published sources } \\
\text { of industry } \\
\text { averages. }\end{array}$ & $\begin{array}{l}\text { We identify four factors } \\
\text { that potentially impact } \\
\text { the } \\
\text { outcome of industrial } \\
\text { case studies: } \\
\text { availability of data, tool } \\
\text { support, cooperative } \\
\text { personnel and project } \\
\text { status. Recognizing } \\
\text { and planning for these } \\
\text { factors is essential to } \\
\text { conducting industrial } \\
\text { case studies }\end{array}$ & $\begin{array}{l}\text { We discuss our } \\
\text { experience in } \\
\text { conducting this case } \\
\text { study, including } \\
\text { specifics of how data } \\
\text { was collected, the } \\
\text { rationale behind our } \\
\text { process of data } \\
\text { collection, and what } \\
\text { obstacles were } \\
\text { encountered during } \\
\text { the case study. }\end{array}$ & $\begin{array}{l}\text { The presence } \\
\text { of CASE tools, including } \\
\text { automated build tools, } \\
\text { integration environments, } \\
\text { and defect tracking } \\
\text { systems, may alleviate } \\
\text { much of the overhead } \\
\text { associated } \\
\text { with collecting these } \\
\text { metrics. }\end{array}$ & [22] \\
\hline 10 & $\begin{array}{l}\text { ACM SIGSOFT } \\
(\mathrm{SEN}) 2005\end{array}$ & $\begin{array}{l}\text { Quantitative } \\
\text { method }\end{array}$ & $\begin{array}{l}\text { Investigate the } \\
\text { organization to } \\
\text { investigate the } \\
\text { impact of the } \\
\text { customer } \\
\text { developer's } \\
\text { discussion }\end{array}$ & $\begin{array}{l}\text { The nature of XP } \\
\text { provides itself strong } \\
\text { psychology } \\
\text { Participants and their } \\
\text { pressure have a positive } \\
\text { effect } \\
\text { Interaction and thus } \\
\text { motivated }\end{array}$ & $\begin{array}{l}\text { Creating a specific } \\
\text { attitude of personal } \\
\text { follow-up control, } \\
\text { So in our case, } \\
\text { motivate, and } \\
\text { investigate } \\
\text { Evaluating the main } \\
\text { reasons for these } \\
\text { behaviour } \\
\text { Follow current social } \\
\text { psychological ideas. }\end{array}$ & $\begin{array}{l}\text { Their effect } \\
\text { Customer and manufacturer } \\
\text { interactions are not } \\
\text { properly monitored } \\
\text { And lower it }\end{array}$ & [23] \\
\hline 11 & $\begin{array}{l}\text { IST } \\
2008\end{array}$ & $\begin{array}{l}\text { Qualitative } \\
\text { analysis }\end{array}$ & $\begin{array}{l}\text { To find Low } \\
\text { requirements for } \\
\text { low quality } \\
\text { software } \\
\text { Compressed } \\
\text { timeline is born } \\
\text { and the number is } \\
\text { low. }\end{array}$ & $\begin{array}{l}\text { This article will show } \\
\text { two } \\
\text { Successful industrial } \\
\text { software projects are } \\
\text { completely different } \\
\text { Aspect; However, both } \\
\text { of them still use } \\
\text { abundant methods to } \\
\text { solve social issues } \\
\text { Factors }\end{array}$ & $\begin{array}{l}\text { The thesis } \\
\text { It will also provide } \\
\text { lessons and tips } \\
\text { Retro view reviews } \\
\text { and observations. }\end{array}$ & $\begin{array}{l}\text { Organization factors are } \\
\text { also need to be address. }\end{array}$ & [81] \\
\hline 12 & $\begin{array}{l}\text { IST } \\
2008\end{array}$ & $\begin{array}{l}\text { Systematic } \\
\text { Literature } \\
\text { review }\end{array}$ & $\begin{array}{l}\text { Review a } \\
\text { systematic } \\
\text { movement of } \\
\text { motion movement } \\
\text { in software } \\
\text { engineering. The } \\
\text { purpose of this } \\
\text { review } \\
\text { How encourages } \\
\text { developers and } \\
\text { encourages } \\
\text { developers and } \\
\text { how to find } \\
\text { current reporting } \\
\text { knowledge } \\
\text { The model } \\
\text { encourages. }\end{array}$ & $\begin{array}{l}\text { Our key } \\
\text { It has come to know } \\
\text { that the concern model } \\
\text { released in software } \\
\text { engineering is } \\
\text { completely different } \\
\text { and does not reflect the } \\
\text { complex needs of the } \\
\text { software. } \\
\text { Engineers are in their } \\
\text { professional stage, } \\
\text { cultural and } \\
\text { environmental settings. }\end{array}$ & $\begin{array}{l}\text { Literature on the } \\
\text { promotion of } \\
\text { software engineering } \\
\text { suggests } \\
\text { controversial and } \\
\text { local explanation in } \\
\text { this field. Very clear } \\
\text { Depending on the } \\
\text { encouraging context } \\
\text { and the engineer is } \\
\text { different from the } \\
\text { engineer. }\end{array}$ & $\begin{array}{l}\text { Our survey results show } \\
\text { that there is no clear } \\
\text { understanding of the work } \\
\text { of software engineers, how } \\
\text { software engineers } \\
\text { encourage them, and how } \\
\text { they encourage them. } \\
\text { Promote, or encourage the } \\
\text { results and advantages of } \\
\text { software engineer. }\end{array}$ & [82] \\
\hline 13 & KMIS & Regression & To implement the & MPS & We will discuss the & The & [29] \\
\hline
\end{tabular}




\begin{tabular}{|c|c|c|c|c|c|c|c|}
\hline & 2009 & analysis & $\begin{array}{l}\text { filter method, } \\
\text { possible scores of } \\
\text { motivation }\end{array}$ & $\begin{array}{l}\text { Affects positive work } \\
\text { like work performance } \\
\text { and development of } \\
\text { system quality The } \\
\text { project does not affect } \\
\text { the duration of the } \\
\text { project, }\end{array}$ & $\begin{array}{l}\text { actual importance } \\
\text { Based on this } \\
\text { experience. }\end{array}$ & $\begin{array}{l}\text { Reduction of job } \\
\text { performance measurements } \\
\text { The purpose and stability is } \\
\text { because it is completely } \\
\text { According to the theme's } \\
\text { opinion }\end{array}$ & \\
\hline 14 & $\begin{array}{l}\text { 5th Internationa } \\
\text { (IRWITPM } \\
\text { 2010) }\end{array}$ & $\begin{array}{l}\text { Qualitative } \\
\text { analysis }\end{array}$ & $\begin{array}{l}\text { This research is a } \\
\text { stimulus study to } \\
\text { study using three } \\
\text { investigative } \\
\text { methods - daily } \\
\text { daily, } \\
\text { Enhanced and } \\
\text { radical planning } \\
\text { and initial reviews }\end{array}$ & $\begin{array}{l}\text { The results show the } \\
\text { practices of these two } \\
\text { countries } \\
\text { The team can } \\
\text { contribute and motivate } \\
\text { the excitement of the } \\
\text { team } \\
\text { One another }\end{array}$ & $\begin{array}{l}\text { Research in areas of } \\
\text { encouragement and } \\
\text { development of } \\
\text { angel's software } \\
\text { development by } \\
\text { identifying the } \\
\text { auxiliary factors } \\
\text { And on the } \\
\text { promotion of angels' }\end{array}$ & $\begin{array}{l}\text { Development teams of the } \\
\text { Angels, the ban is related to } \\
\text { the formation of the team. } \\
\text { Even trouble } \\
\text { The procedure in a team is } \\
\text { only implemented recently. } \\
\text { Both teams are well- } \\
\text { established and familiar }\end{array}$ & [60] \\
\hline 15 & $\begin{array}{l}\text { KAU } \\
\text { (2013), Karlstad } \\
\text { Business School. }\end{array}$ & $\begin{array}{l}\text { Systematic } \\
\text { Literature } \\
\text { Review }\end{array}$ & $\begin{array}{l}\text { Determine the } \\
\text { importance and } \\
\text { encouragement of } \\
\text { the report } \\
\text { Participants use } \\
\text { partial methods in } \\
\text { project } \\
\text { participants }\end{array}$ & $\begin{array}{l}\text { A list of research paper } \\
\text { on project management } \\
\text { has been reported. }\end{array}$ & $\begin{array}{l}\text { There exist a detail } \\
\text { list of motivator and } \\
\text { demotivator from } \\
\text { Systematic literature } \\
\text { review with respect } \\
\text { to project } \\
\text { management. }\end{array}$ & $\begin{array}{l}\text { The ability to study is } \\
\text { limited to harmony journal } \\
\text { arts. Initial examination } \\
\text { search } \\
\text { Some databases, including } \\
\text { conference papers, made a } \\
\text { large number of results. }\end{array}$ & [83] \\
\hline 16 & $\begin{array}{l}\text { Management } \\
\text { Prudence Journal } \\
(2010)\end{array}$ & $\begin{array}{l}\text { Statistical } \\
\text { analysis }\end{array}$ & $\begin{array}{l}\text { The impact of job } \\
\text { conversions is } \\
\text { even more } \\
\text { pronounced. This } \\
\text { area is relatively } \\
\text { new } \\
\text { Lack of value and } \\
\text { encouragement for } \\
\text { her caravan. }\end{array}$ & $\begin{array}{l}\text { Compared with the low } \\
\text { Protestant Ec Group, } \\
\text { the High Group } \\
\text { encourages high } \\
\text { interviews, which } \\
\text { means that there is a } \\
\text { high interest in high } \\
\text { technology, more } \\
\text { interest/enjoyment, } \\
\text { qualifications, choice of } \\
\text { choice, but } \\
\text { pressure/stress is lower } \\
\text { than the low outlook } \\
\text { job. }\end{array}$ & $\begin{array}{l}\text { Having chosen it will } \\
\text { receive the highest } \\
\text { level of } \\
\text { encouragement, } \\
\text { which will have an } \\
\text { effective impact on } \\
\text { their profession. }\end{array}$ & $\begin{array}{l}\text { Work value training should } \\
\text { be part of the plan, which } \\
\text { will help improve the } \\
\text { performance of new jobs. }\end{array}$ & [41] \\
\hline 17 & $\begin{array}{l}\text { PROFES } \\
2014\end{array}$ & $\begin{array}{l}\text { Qualitative } \\
\text { analysis }\end{array}$ & $\begin{array}{l}\text { Investigates our } \\
\text { research factors } \\
\text { that lead to } \\
\text { software testing } \\
\text { professionals } \\
\text { Work, choice and } \\
\text { stay in the duties } \\
\text { and customs } \\
\text { practices }\end{array}$ & $\begin{array}{l}\text { This career path can } \\
\text { help the results } \\
\text { During the recruitment } \\
\text { process the company } \\
\text { runs on a traditionally } \\
\text { transit } \\
\text { Encouraged } \\
\text { entrepreneurs } \\
\text { encourage internal and } \\
\text { their examinations, } \\
\text { which will improve } \\
\text { Job satisfaction and } \\
\text { productivity. }\end{array}$ & $\begin{array}{l}\text { We provide a series } \\
\text { of factors that have } \\
\text { negative and positive } \\
\text { effects on daily life. } \\
\text { Software tester } \\
\text { activities and other } \\
\text { types have been } \\
\text { included } \\
\text { Software published } \\
\text { in the field of } \\
\text { engineering and } \\
\text { published. }\end{array}$ & $\begin{array}{l}\text { Our research plan presents } \\
\text { this study into further } \\
\text { content } \\
\text { Besides checking the } \\
\text { company and exam } \\
\text { properties and more } \\
\text { Relationship with } \\
\text { colleagues }\end{array}$ & [84] \\
\hline 18 & $\begin{array}{l}\text { 38th Euromicro } \\
\text { Conference } \\
\text { (SEAA) } 2012\end{array}$ & $\begin{array}{l}\text { Systematic } \\
\text { literature } \\
\text { review }\end{array}$ & $\begin{array}{l}\text { Our research } \\
\text { What is motivated } \\
\text { is designed to } \\
\text { better understand } \\
\text { Software } \\
\text { developers in } \\
\text { imagination } \\
\text { environments. }\end{array}$ & $\begin{array}{l}\text { Our research results } \\
\text { show that in spite of } \\
\text { trouble } \\
\text { The background and } \\
\text { motivation overall } \\
\text { approach is slightly } \\
\text { different } \\
\text { In general software } \\
\text { development. }\end{array}$ & $\begin{array}{l}\text { We have done three } \\
\text { cases } \\
\text { The fireplace } \\
\text { company to confirm } \\
\text { our results and to } \\
\text { collect new } \\
\text { information }\end{array}$ & $\begin{array}{l}\text { To increase confidence } \\
\text { factors, we use it very well } \\
\text { Created in established } \\
\text { investigative methods and } \\
\text { early dates } \\
\text { By orientation with } \\
\text { organizational culture } \\
\text { Early visit }\end{array}$ & [3] \\
\hline 19 & $\begin{array}{l}\text { SJIS } \\
2011\end{array}$ & $\begin{array}{l}\text { Qualitative } \\
\text { analysis }\end{array}$ & $\begin{array}{l}\text { It is an } \\
\text { investigation } \\
\text { study of the } \\
\text { Swedish and Irish } \\
\text { IT Project Team } \\
\text { Investigate the } \\
\text { three duties, will } \\
\text { stand daily }\end{array}$ & $\begin{array}{l}\text { The results of both } \\
\text { cases show that in } \\
\text { germing methods can } \\
\text { occur } \\
\text { The team encourages }\end{array}$ & $\begin{array}{l}\text { Encourages the team } \\
\text { to encourage and } \\
\text { contribute } \\
\text { significantly to the } \\
\text { field of floor project } \\
\text { management. } \\
\text { Identifying the } \\
\text { factors that help in }\end{array}$ & $\begin{array}{l}\text { Project team study is } \\
\text { limited } \\
\text { Because only two APM } \\
\text { teams have been examined. } \\
\text { There are two teams } \\
\text { Get acquainted and familiar } \\
\text { with each other. }\end{array}$ & [85] \\
\hline
\end{tabular}




\begin{tabular}{|c|c|c|c|c|c|c|c|}
\hline & & & $\begin{array}{l}\text { Planning and } \\
\text { revised reviews } \\
\text { can motivate or } \\
\text { encourage harm in } \\
\text { an active team. } \\
\end{array}$ & & $\begin{array}{l}\text { encouraging IT and } \\
\text { prevent IT }\end{array}$ & & \\
\hline 20 & $\begin{array}{l}\text { SPI } \\
2006\end{array}$ & $\begin{array}{l}\text { Qualitative } \\
\text { Analysis }\end{array}$ & $\begin{array}{l}\text { Especially how to } \\
\text { encourage the } \\
\text { development to } \\
\text { influence growth } \\
\text { Work in software } \\
\text { engineering. }\end{array}$ & $\begin{array}{l}\text { Our main result is that } \\
\text { good software } \\
\text { developers } \\
\text { Active, flexible and } \\
\text { applicable to share and } \\
\text { follow knowledge with } \\
\text { the team } \\
\text { Exercises, such as } \\
\text { recording work. }\end{array}$ & $\begin{array}{l}\text { We found } \\
\text { According to } \\
\text { technical capabilities, } \\
\text { mutual expertise and } \\
\text { good practices, } \\
\text { compliance with all } \\
\text { positive effects are } \\
\text { related } \\
\text { About the success of } \\
\text { software projects.. }\end{array}$ & $\begin{array}{l}\text { Looking at the current } \\
\text { trend } \\
\text { Software development, } \\
\text { which will be helpful } \\
\text { Compare the results of this } \\
\text { study with the same study } \\
\text { In a delicate environment }\end{array}$ & [64] \\
\hline 21 & $\begin{array}{l}\text { APSEEP } \\
2007\end{array}$ & $\begin{array}{l}\text { Qualitative } \\
\text { analysis }\end{array}$ & $\begin{array}{l}\text { This study finds } \\
\text { different aspects } \\
\text { of team planning } \\
\text { Attached, } \\
\text { positively related } \\
\text { to psychological } \\
\text { events } \\
\text { Traditional } \\
\text { management, out } \\
\text { of the era of } \\
\text { organization } \\
\text { And software } \\
\text { engineering } \\
\text { research. }\end{array}$ & $\begin{array}{l}\text { Results include } \\
\text { profound understanding } \\
\text { Relationships between } \\
\text { responsibilities and } \\
\text { active team results, } \\
\text { such as } \\
\text { Motivation and } \\
\text { harmony. }\end{array}$ & $\begin{array}{l}\text { Looks very strong } \\
\text { Add operations and } \\
\text { effects }\end{array}$ & $\begin{array}{l}\text { A deeper knowledge of } \\
\text { socio knowledge is still } \\
\text { need to explore. }\end{array}$ & [86] \\
\hline 22 & $\begin{array}{l}\text { In Proceedings of } \\
15 \text { th international } \\
\text { conference, } \\
\mathrm{XP}(2014)\end{array}$ & $\begin{array}{l}\text { Qualitative } \\
\text { analysis }\end{array}$ & $\begin{array}{l}\text { Several case } \\
\text { design issues have } \\
\text { been introduced } \\
\text { In three different } \\
\text { instant software } \\
\text { organizations. }\end{array}$ & $\begin{array}{l}\text { We lie } \\
\text { The organization } \\
\text { created a culture that } \\
\text { supports } \\
\text { communication and } \\
\text { discussion } \\
\text { There is less agility } \\
\text { than alternative two } \\
\text { organizations to design } \\
\text { decisions. }\end{array}$ & $\begin{array}{l}\text { Our theory is that } \\
\text { Gulf Environment } \\
\text { generates more open } \\
\text { communication } \\
\text { among developers, } \\
\text { which can lead } \\
\text { developers to } \\
\text { challenge each } \\
\text { other's design } \\
\text { solutions and to } \\
\text { enhance their } \\
\text { likeness accordingly. }\end{array}$ & $\begin{array}{l}\text { Review the effect of long- } \\
\text { term experimental study } \\
\text { design decisions. }\end{array}$ & [87] \\
\hline 23 & $\begin{array}{l}\text { Agile Times } \\
2004\end{array}$ & $\begin{array}{l}\text { Qualitative } \\
\text { analysis }\end{array}$ & $\begin{array}{l}\text { This research is } \\
\text { contribution } \\
\text { towards motivator } \\
\text { factor of agile } \\
\text { software } \\
\text { development to } \\
\text { increase the } \\
\text { productivity and } \\
\text { morale. }\end{array}$ & $\begin{array}{l}\text { Their role in the use of } \\
\text { processes and } \\
\text { equipment that } \\
\text { influence }\end{array}$ & $\begin{array}{l}\text { The most important } \\
\text { elements of } \\
\text { processing and } \\
\text { encouragement is } \\
\text { still very important } \\
\text { because they are } \\
\text { accustomed to it. } \\
\text { Focus on all } \\
\text { repetitive tasks and } \\
\text { focus on what } \\
\text { developers are really } \\
\text { focused on: the need } \\
\text { for things } \\
\text { Customers through } \\
\text { the production of } \\
\text { valuable software }\end{array}$ & $\begin{array}{l}\text { Motivators should also be } \\
\text { find against the Non- } \\
\text { functional requirements. }\end{array}$ & [33] \\
\hline 24 & $\begin{array}{l}\text { Journal of } \\
\text { Systems and } \\
\text { Software } \\
2008\end{array}$ & $\begin{array}{l}\text { Statistical } \\
\text { analysis }\end{array}$ & $\begin{array}{l}\text { Afterwards, an } \\
\text { analysis of } \\
\text { reliability and } \\
\text { elemental analysis } \\
\text { was performed in } \\
\text { the initial list to } \\
\text { reinforce the } 12 \\
\text { potential key } \\
\text { endpoint sets. } \\
\text { The type of } \\
\text { success for each } \\
\text { of the four } \\
\text { projects - quality } \\
\text { factors, scope, } \\
\text { time, and success }\end{array}$ & $\begin{array}{l}\text { The results showed that } \\
\text { only } 10 \text { of the } 48 \\
\text { governors were } \\
\text { supported and } \\
\text { identified the three } \\
\text { major success factors of } \\
\text { the fire. } \\
\text { Software development } \\
\text { projects: (a) delivery } \\
\text { strategy, (b) Elevail } \\
\text { software engineering } \\
\text { technology, and (c) } \\
\text { team capabilities. }\end{array}$ & $\begin{array}{l}\text { The main part of this } \\
\text { study is to obtain the } \\
\text { key success factors } \\
\text { of the three factors in } \\
\text { this incident. } \\
\text { According to survey } \\
\text { data analysis. }\end{array}$ & $\begin{array}{l}\text { To ensure the success of } \\
\text { their project, managers } \\
\text { To focus on high-quality } \\
\text { team teams, follow the } \\
\text { ferrous metal process } \\
\text { technology and the above } \\
\text { delivery strategies. }\end{array}$ & [7] \\
\hline
\end{tabular}




\begin{tabular}{|c|c|c|c|c|c|c|c|}
\hline & & & $\begin{array}{l}\text { factors for each } \\
\text { cost. }\end{array}$ & & & & \\
\hline 25 & $\begin{array}{l}\text { PHD Thesis } \\
2012\end{array}$ & $\begin{array}{l}\text { Qualitative and } \\
\text { Quantitative } \\
\text { analysis }\end{array}$ & $\begin{array}{l}\text { This study has } \\
\text { investigated the } \\
\text { factors of major } \\
\text { success involved } \\
\text { in the pilot system } \\
\text { Development } \\
\text { plans of different } \\
\text { system } \\
\text { development } \\
\text { methods and } \\
\text { projects } \\
\text { Tracking their } \\
\text { basic principles } \\
\text { and benefits to } \\
\text { management } \\
\text { practices }\end{array}$ & $\begin{array}{l}\text { And the weaknesses } \\
\text { show their results that } \\
\text { actually are } 16 \\
\text { Key-success factors } \\
\text { that have directly } \\
\text { impacted the financial } \\
\text { system success } \\
\text { Development project }\end{array}$ & $\begin{array}{l}\text { Institutions should } \\
\text { encourage these } \\
\text { important successes } \\
\text { The effect of } \\
\text { implementing ASDM } \\
\text { when this project has } \\
\text { a positive impact }\end{array}$ & $\begin{array}{l}\text { Findings of major success } \\
\text { factors in the } \\
\text { responsibilities system } \\
\text { Extensive development } \\
\text { projects, including the } \\
\text { largest number } \\
\text { Project }\end{array}$ & {$[6]$} \\
\hline 26 & (XP 2007) & $\begin{array}{l}\text { Qualitative } \\
\text { analysis }\end{array}$ & $\begin{array}{l}\text { Autonomy, } \\
\text { multiple factors, } \\
\text { The importance of } \\
\text { completing the } \\
\text { importance, } \\
\text { opinion, and } \\
\text { completion of } \\
\text { work is very } \\
\text { important } \\
\text { Ensure factors of } \\
\text { satisfaction and } \\
\text { encouragement } \\
\text { among workers. }\end{array}$ & $\begin{array}{l}\text { Maintain software } \\
\text { agility } \\
\text { With the development } \\
\text { of software and } \\
\text { developer team } \\
\text { development, it is } \\
\text { slowly increasing } \\
\text { Like biology, both of } \\
\text { them are constantly } \\
\text { considering } \\
\text { management } \\
\text { Business value and } \\
\text { encouragement } \\
\text { questions about } \\
\text { motivation and } \\
\text { decision-making } \\
\text { Change our } \\
\text { independence, variety }\end{array}$ & $\begin{array}{l}\text { The importance of } \\
\text { completing the entire } \\
\text { mission, opinions } \\
\text { and abilities are } \\
\text { essential } \\
\text { In this project. }\end{array}$ & $\begin{array}{l}\text { A Quantitative analysis is } \\
\text { needed to find in-depth } \\
\text { results. }\end{array}$ & [36] \\
\hline 27 & $\begin{array}{l}\text { IEEE Software ( } \\
\text { Volume: } 28 \text {, } \\
\text { Issue: } 4 \text {, July- } \\
\text { Aug. 2011 ) }\end{array}$ & $\begin{array}{l}\text { Qualitative } \\
\text { analysis }\end{array}$ & $\begin{array}{l}\text { They apply the } \\
\text { angels' } \\
\text { implementation in } \\
\text { an advanced form } \\
\text { In cross } \\
\text { organizations or at } \\
\text { least business } \\
\text { entities. }\end{array}$ & $\begin{array}{l}\text { It is difficult to measure } \\
\text { all the methods } \\
\text { According to } \\
\text { respondents, steps } \\
\text { taken in at least one } \\
\text { organization have been } \\
\text { taken: } \\
\text { In every case. }\end{array}$ & $\begin{array}{l}\text { They found out } \\
\text { different challenges } \\
\text { from literature and } \\
\text { give recommendation } \\
\text { accordingly. }\end{array}$ & $\begin{array}{l}\text { Some } \\
\text { concerns were considered } \\
\text { by institutes, people, } \\
\text { technical and process is } \\
\text { need to explore. }\end{array}$ & [18] \\
\hline 28 & $\begin{array}{l}\text { Proceedings - } \\
\text { IEEE AGILE } \\
2007\end{array}$ & $\begin{array}{l}\text { Qualitative } \\
\text { analysis }\end{array}$ & $\begin{array}{l}\text { Five adult team } \\
\text { consultations } \\
\text { Consider whether } \\
\text { this feature is the } \\
\text { indicator } \\
\text { The XP } \\
\text { environment } \\
\text { exists. }\end{array}$ & $\begin{array}{l}\text { We found that the XP } \\
\text { Team has entered } \\
\text { There is a proper } \\
\text { process in our research } \\
\text { to support many } \\
\text { operations } \\
\text { One developer needs to } \\
\text { be encouraged } \\
\text { Traditional } \\
\text { Heavyweight Software } \\
\text { Development } \\
\text { The environment }\end{array}$ & $\begin{array}{l}\text { In our research, five } \\
\text { XT teams are already } \\
\text { under process } \\
\text { Supports many } \\
\text { encouraging needs } \\
\text { Traditional, } \\
\text { Heavy Weight } \\
\text { software } \\
\text { development } \\
\text { environment. }\end{array}$ & $\begin{array}{l}\text { The XP environment is } \\
\text { contrary to it } \\
\text { Other motivation is needed }\end{array}$ & [17] \\
\hline 29 & $\begin{array}{l}(\mathrm{XP} 2006) \\
7^{\text {th }} \text { international } \\
\text { Conference }\end{array}$ & $\begin{array}{l}\text { Statistical } \\
\text { analysis }\end{array}$ & $\begin{array}{l}\text { How and how to } \\
\text { increase employee } \\
\text { satisfaction with } \\
\text { the development } \\
\text { process } \\
\text { Identify widely } \\
\text { used teams and } \\
\text { employee } \\
\text { satisfaction } \\
\text { Area and staff. }\end{array}$ & $\begin{array}{l}\text { This one } \\
\text { The three most } \\
\text { powerful relationships } \\
\text { have the ability to } \\
\text { influence decisions } \\
\text { Affect people and add } \\
\text { interesting items }\end{array}$ & $\begin{array}{l}\text { How much trouble } \\
\text { does the team } \\
\text { member have with } \\
\text { the user/customer } \\
\text { twice? } \\
\text { His job satisfaction } \\
\text { (compared to non- } \\
\text { dynamic teams). }\end{array}$ & $\begin{array}{l}\text { Analyse perceived } \\
\text { desirability of movement } \\
\text { and work stress. }\end{array}$ & [39] \\
\hline 30 & $\begin{array}{l}\text { Crosstalk } \\
\text { Technology } 2004\end{array}$ & $\begin{array}{l}\text { Qualitative } \\
\text { analysis }\end{array}$ & $\begin{array}{l}\text { Identify potential } \\
\text { risks, problems } \\
\text { and strategies } \\
\text { Help your project }\end{array}$ & $\begin{array}{l}\text { Learn } \\
\text { More efficient through } \\
\text { service methods } \\
\text { Development and }\end{array}$ & $\begin{array}{l}\text { Emotionally } \\
\text { emotional emotions } \\
\text { often appear } \\
\text { Cause of basic }\end{array}$ & $\begin{array}{l}\text { Agent does not violate } \\
\text { effective project } \\
\text { management, but what } \\
\text { happens in practice }\end{array}$ & [45] \\
\hline
\end{tabular}




\begin{tabular}{|c|c|c|c|c|c|c|c|}
\hline & & & $\begin{array}{l}\text { and organization } \\
\text { succeed. }\end{array}$ & $\begin{array}{l}\text { communication } \\
\text { measurement } \\
\text { technology. }\end{array}$ & $\begin{array}{l}\text { damage } \\
\text { Communication. }\end{array}$ & $\begin{array}{l}\text { Not all project management } \\
\text { provides } \\
\text { Need to be successful. }\end{array}$ & \\
\hline 31 & $\begin{array}{l}\text { IEEE Software } \\
2005\end{array}$ & $\begin{array}{l}\text { Qualitative } \\
\text { analysis }\end{array}$ & $\begin{array}{l}\text { Identify } \\
\text { screenshots } \\
\text { instead of } \\
\text { technology and } \\
\text { some of the } \\
\text { obstacles to } \\
\text { dynamic the } \\
\text { traditional } \\
\text { approach. }\end{array}$ & $\begin{array}{l}\text { Learning lessons can } \\
\text { help more } \\
\text { Enhances high speed } \\
\text { integration } \\
\text { Disadvantaged methods } \\
\text { and methods and } \\
\text { experiences across the } \\
\text { organization }\end{array}$ & $\begin{array}{l}\text { And the entire } \\
\text { community's data is } \\
\text { important for the } \\
\text { return on investment } \\
\text { verification and } \\
\text { integration activities. }\end{array}$ & $\begin{array}{l}\text { Research } \\
\text { There are many areas } \\
\text { where new methods and } \\
\text { uniforms need to be } \\
\text { provided. }\end{array}$ & {$[20]$} \\
\hline 32 & Computer 2001 & $\begin{array}{l}\text { Qualitative } \\
\text { analysis }\end{array}$ & $\begin{array}{l}\text { Exploratory } \\
\text { problem areas are } \\
\text { extremely, } \\
\text { complex, highly } \\
\text { variable }\end{array}$ & $\begin{array}{l}\text { The project's ability to } \\
\text { work, cooperates and } \\
\text { works best on people } \\
\text { Culture. }\end{array}$ & $\begin{array}{l}\text { Detailed discussion } \\
\text { of factor that } \\
\text { influence agile with } \\
\text { people, organization } \\
\text { and technical. }\end{array}$ & $\begin{array}{l}\text { Systematic literature } \\
\text { review is needed to gauge } \\
\text { more factors influencing } \\
\text { Agile }\end{array}$ & {$[21]$} \\
\hline 33 & $\begin{array}{l}\text { International } \\
\text { Journal of } \\
\text { Quality \& } \\
\text { Reliability } \\
\text { Management } \\
2012\end{array}$ & $\begin{array}{l}\text { Systematic } \\
\text { literature } \\
\text { review }\end{array}$ & $\begin{array}{l}\text { Researchers need } \\
\text { to investigate } \\
\text { trust, } \\
\text { confidentiality, } \\
\text { and security issues } \\
\text { associated with } \\
\text { them } \\
\text { ASD. }\end{array}$ & $\begin{array}{l}\text { Concepts and principles } \\
\text { ASD, history and } \\
\text { evolution, and criticism } \\
\text { of different users } \\
\text { Software development } \\
\text { community }\end{array}$ & $\begin{array}{l}\text { Generic view of ASD } \\
\text { is briefly described. }\end{array}$ & $\begin{array}{l}\text { Researchers also want to } \\
\text { deal with success factors } \\
\text { and make necessary } \\
\text { changes } \\
\text { Challenges in adjusting } \\
\text { ASD in Outsourcing / } \\
\text { Outside Sensing }\end{array}$ & [76] \\
\hline 34 & $\begin{array}{l}\text { DOI } \\
2015\end{array}$ & $\begin{array}{l}\text { Qualitative } \\
\text { analysis }\end{array}$ & $\begin{array}{l}\text { What separates } \\
\text { successful agility? }\end{array}$ & $\begin{array}{l}\text { Software Project and } \\
\text { Minimum Team } \\
\text { Successful and busy } \\
\text { team and team leader } \\
\text { Follow different } \\
\text { strategies. They - } \\
\text { obviously or (rarely) } \\
\text { are obviously } \\
\text { intentional } \\
\text { Software development } \\
\text { is a multi-domain } \\
\text { Take questions and } \\
\text { related tasks. }\end{array}$ & $\begin{array}{l}\text { When different } \\
\text { people or groups } \\
\text { People are involved } \\
\text { and we are generally } \\
\text { dealing with complex } \\
\text { (adaptive) systems. }\end{array}$ & $\begin{array}{l}\text { There is no "perfect size" } \\
\text { According to procedures } \\
\text { and actions, the problem } \\
\text { lies in this issue. }\end{array}$ & {$[28]$} \\
\hline 35 & $\begin{array}{l}\text { CROSSTALK } \\
\text { The Journal of } \\
\text { Defence } \\
\text { Software } \\
\text { Engineering } \\
2004\end{array}$ & $\begin{array}{l}\text { Qualitative } \\
\text { analysis }\end{array}$ & $\begin{array}{l}\text { To provide } \\
\text { awareness about } \\
\text { risk management } \\
\text { and to provide a } \\
\text { vision for } \\
\text { developing the } \\
\text { appropriate risk } \\
\text { management } \\
\text { strategy }\end{array}$ & $\begin{array}{l}\text {, we identified six risks. } \\
\text { The potential factors } \\
\text { according to our } \\
\text { experience } \\
\text { There is also a } \\
\text { significant impact on } \\
\text { success } \\
\text { Software programs and } \\
\text { projects failed. }\end{array}$ & $\begin{array}{l}\text { By following these } \\
\text { points, you can } \\
\text { reduce the possibility } \\
\text { of a program or } \\
\text { project failure. }\end{array}$ & $\begin{array}{l}\text { This article does not intend } \\
\text { to provide a complete list } \\
\text { of risk factors for a specific } \\
\text { program / project - it } \\
\text { requires more } \\
\text { Space. }\end{array}$ & [44] \\
\hline 36 & XP 2002 & $\begin{array}{l}\text { Qualitative } \\
\text { analysis }\end{array}$ & $\begin{array}{l}\text { To support the } \\
\text { selection of the } \\
\text { procedure } \\
\text { Experience based } \\
\text { on submitting and } \\
\text { analysing the } \\
\text { applicable } \\
\text { methods } \\
\text { And get } \\
\text { background } \\
\text { experience. }\end{array}$ & $\begin{array}{l}\text { This experience is once } \\
\text { again } \\
\text { Ability to support and } \\
\text { guide future projects to } \\
\text { select the most } \\
\text { appropriate assets } \\
\text { Hand job }\end{array}$ & $\begin{array}{l}\text { Carefully check and } \\
\text { challenge future } \\
\text { plans and when they } \\
\text { maintain the } \\
\text { environment } \\
\text { When they should } \\
\text { not be caught }\end{array}$ & $\begin{array}{l}\text { A detail cross talk is } \\
\text { needed to explore more } \\
\text { challenges that effect } \\
\text { Agile. }\end{array}$ & [38] \\
\hline 37 & $\begin{array}{l}\text { IJPOM } \\
2012\end{array}$ & $\begin{array}{l}\text { Statistical } \\
\text { analysis }\end{array}$ & $\begin{array}{l}\text { We have an } \\
\text { integrated } \\
\text { development idea } \\
\text { The model affects } \\
\text { the project } \\
\text { manager's } \\
\text { encouragement, } \\
\text { "Movement } \\
\text { Factor Inventory" } \\
\text { (MFI). }\end{array}$ & $\begin{array}{l}\text { A clear, interesting task } \\
\text { is working with a } \\
\text { supportive and } \\
\text { objective based team to } \\
\text { get the necessary } \\
\text { information } \\
\text { The possibility of } \\
\text { influencing financial } \\
\text { and human resources } \\
\text { and important decisions }\end{array}$ & $\begin{array}{l}\text { The } \\
\text { Governments can } \\
\text { positively influence } \\
\text { the encouragement of } \\
\text { project managers. }\end{array}$ & $\begin{array}{l}\text { Future } \\
\text { These important issues } \\
\text { related to research need to } \\
\text { be solved } \\
\text { Personal, situations and } \\
\text { active variables } \\
\text { Project Manager } \\
\text { encourages }\end{array}$ & [26] \\
\hline
\end{tabular}




\begin{tabular}{|l|l|l|l|l|l|l|}
\hline & & & $\begin{array}{l}\text { has been identified as } \\
\text { the most important } \\
\text { concern } \\
\text { Project Manager } \\
\text { working in Switzerland }\end{array}$ & $\begin{array}{l}\text { Detailed list of } \\
\text { motivators and } \\
\text { demotivators is } \\
\text { elaborated and } \\
\text { classified into people } \\
\text { technical and } \\
\text { organization factors. }\end{array}$ & $\begin{array}{l}\text { Providing an } \\
\text { categorization of } \\
\text { motivators with } \\
\text { respect to people, } \\
\text { organization and } \\
\text { technical and sub- } \\
\text { categorization } \\
\text { accordingly. }\end{array}$ & $\begin{array}{l}\text { There is need of model of } \\
\text { motivators for ASD. }\end{array}$ \\
\hline (IJACSA) & $\begin{array}{l}\text { Qualitative } \\
\text { analysis }\end{array}$ & $\begin{array}{l}\text { To find the } \\
\text { detailed list of } \\
\text { motivator and } \\
\text { demotivator } \\
\text { factors }\end{array}$ & [43] & \\
\hline
\end{tabular}

\section{Motivators AND Demotivators IN RQ1}

In order to answer the RQ 1, SLR was done by which detailed list of motivator and demotivator has been extracted and list in Table VI.

\section{A. Common DeMotivators Mined from SLR}

Specific collective demotivators mined from SLR are presented in Table VII.

TABLE VI. COMMON MOTIVATORS EXTRACTED FROM SELECTED PAPERS

\begin{tabular}{|c|c|c|}
\hline Sr. No & Motivator Factors & No. of Existing Studies \\
\hline 1 & High quality Performance & {$[9][79]$} \\
\hline 2 & Adherence to budget & [79] [57] [72] [4] [6] [88] [82] [9] [19] \\
\hline 4 & Personal interest & {$[82][9][19]$} \\
\hline 5 & Quality work & [7] \\
\hline 7 & Feasibility studies & {$[82][9]$} \\
\hline 8 & Recognition of good work & {$[82][19]$} \\
\hline 9 & Teamwork & {$[32][82][9][19]$} \\
\hline 10 & Task Identification & {$[82]$} \\
\hline 11 & Clear domain knowledge & {$[82][9][19]$} \\
\hline 15 & Autonomy & [4] [8] [82] [9] [19] \\
\hline 16 & Follow rules and regulations & [33][89] \\
\hline 17 & Tolerance to work & {$[6][88][82][9]$} \\
\hline 18 & Intime and accurate & {$[82][19]$} \\
\hline 19 & Rapid communication & {$[32][82][19][79]$} \\
\hline 20 & Training & {$[82][9]$} \\
\hline 21 & Minimize risk & {$[82][9][19]$} \\
\hline 22 & Simple code/ Simplicity & {$[90]$} \\
\hline
\end{tabular}


TABLE VII. COMMON DEMOTIVATORS EXTRACTED FROM SELECTED PAPERS

\begin{tabular}{|l|l|l|}
\hline Sr. No & Demotivators factors & No. Of existing studies \\
\hline 1 & Work location & {$[4][82][19][79][91]$} \\
\hline 2 & Low Incentives & {$[6][7][82][9]$} \\
\hline 3 & Large documentation & {$[82][9][19]$} \\
\hline 4 & Uncertain working environment & {$[82]$} \\
\hline 5 & Change in prioritization & {$[82][19]$} \\
\hline 6 & Poor commitment & {$[8][92]$} \\
\hline 7 & Low sense of ownership & {$[82][9][19]$} \\
\hline 8 & Less resources & {$[9]$} \\
\hline 9 & Lack of executive sponsorship & {$[82][9][19]$} \\
\hline 10 & Lack of agile logistic & {$[82][9][19]$} \\
\hline 12 & Lack of necessary skills set & {$[9]$} \\
\hline 13 & Poorly defined scope & {$[9][19]$} \\
\hline 14 & Lack of project tracking mechanism & {$[4][82][9][19]$} \\
\hline
\end{tabular}

\section{CATEGORIZATION OF MOTIVATORS AND DEMOTIVATORS (RQ2)}

We have classified motivators and demotivators factors into procedural, stakeholders and firm's factors as shown in Fig. 1. Following figure shows the general motivators and their classification in which organization of general factors include customer oriented, judgment based, team dissemination and scope, overall culture and organization and mechanism. Stakeholders technical features includes ability, individual features, announcement and conciliation, civilization culture and keeping fit and knowledge while procedural features include individual features, inherent, extrinsic and some overall aspects.

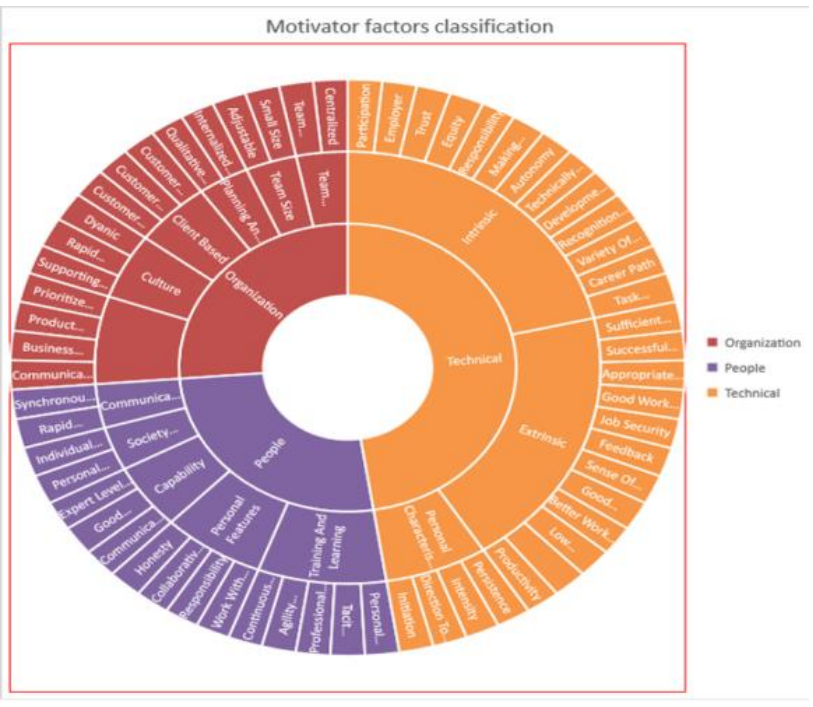

Fig. 1. Classification of motivators.

Classification of demotivators has also been performed to find more precise results (Fig. 2). In organization, the most common factors are: unclear requirement, scope and kind of modification, deadlines, early decision making, current political situation, low productivity, lack of face to face communication, large team size, informal communication, trusting people, tool process, nature of organization. In people factor, less domain experience, critical communication, time zone, native culture, geographical condition and linguistic difficulty are evaluated.

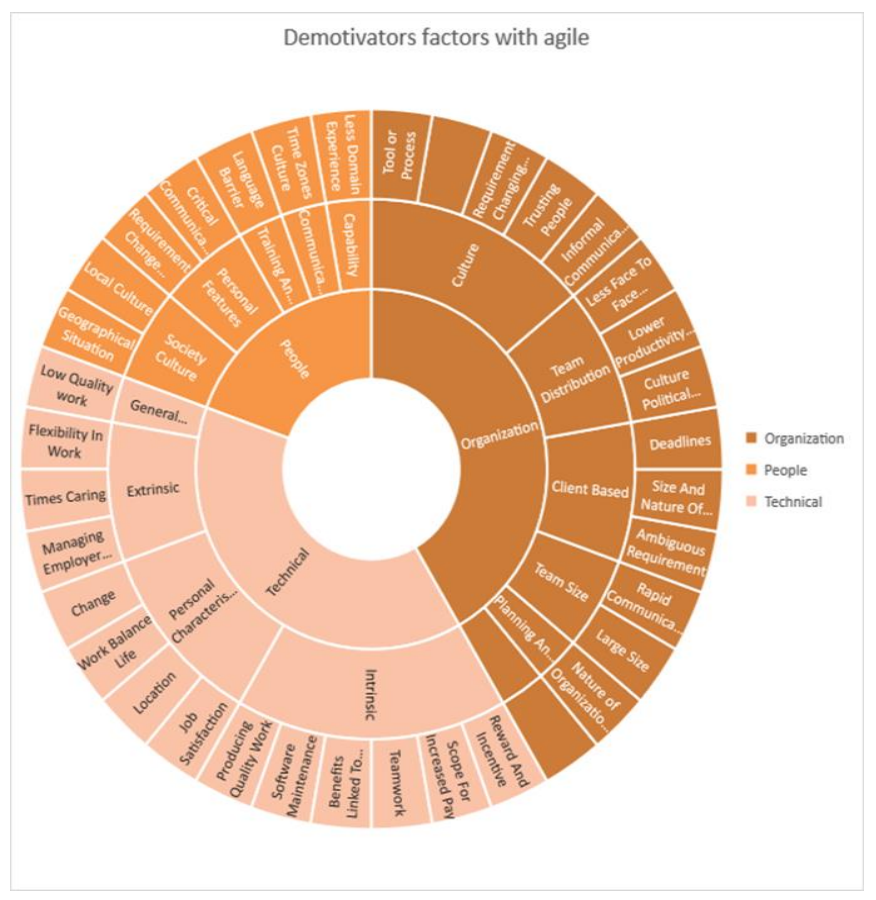

Fig. 2. Classification of demotivator factors.

\section{FACTORIZATION OF MOTIVATORS (RQ3)}

This section addresses the answer of RQ3. Subcategorization was done on motivators (Fig. 3). We have done categorization of motivating factors such as diversity of effort which was categorized as individual and marketplace desires. Considering the sense of belonging aspects are categorised as intrinsic and extrinsic. Recognition of work can be classified as reward and incentive. In employee participation individual and team participation are core motivating factors while clear identification with task has motivating factors such as clear goals and stick with plans. 


\section{Factorization of Motivators}

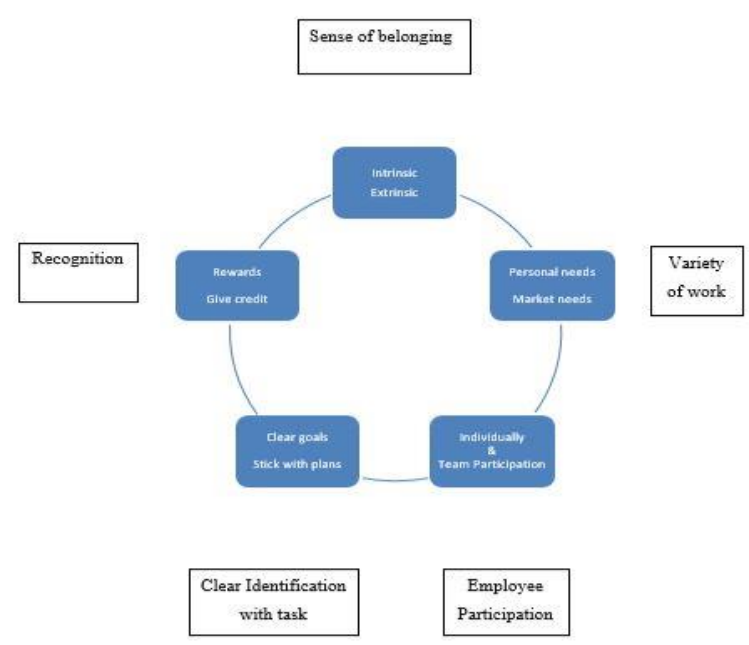

Fig. 3. Factorization of motivator factors.

\section{THREAT TO VALIDITY}

There are three systematic steps for threat to validity perspectives.

\section{A. Primary Studies Risk Identification}

The motivation is the core domain to motivate someone to enhance their capability that is why it is a tuff task to separate concept of motivation accordingly. For this purpose we have selected the word software to differentiate the concept of motivator from other domains.

\section{B. Threats to Selection and Consistency}

Due to selection of research question from the domain of agile their might be possibility of containing magazine contributions and thesis because the data exist in dispersed form.

\section{Threats to Data Fusion and Results}

This result is evaluated against given string. If a keyword is added or remove against string it might be better filtering result. This snowballing process is to explore what has been done in the field of motivator in ASD.

\section{DISCUSSION}

Current research focused a systematic literature review of motivator and demotivator factor of ASD. For this purpose we have explore against the string and evaluate the result accordingly. The detailed list of motivator and demotivator has been evaluated and classification of motivator and demotivator has done on organization, people and technical level. Then these levels are explored more against general factors, such as client based, decision time, team distribution, team size, general culture, planning and controlling, capability to do work, personal feature, training and learning and intrinsic and extrinsic.

\section{CONCLUSION}

This systematic literature describes the synthesis of data available on success and barrier of Agile software development. These success and barrier are also referred as motivator and demotivator factors. For this purpose we have provided a detailed list of motivators and demotivators. Classification is also been performed on the basis of people, technical and organization perspective to give comprehensive detail accordingly. A Quality Assessment has been performed to find the best possible paper according to string. Brief introduction of selected papers has also been described. Along with this, the sub categorization has also been performed to find more brief detail of motivator and demotivator factors. The plan behind this research is described and keywords that support are also been discussed. Literature lacks the open question on challenge and motivator factor of agile software development.

\section{FUTURE WORK}

In future we will do empirical analysis on motivator and demotivator of Agile Software Development to find more accurate results. Further plans are to provide a demotivation effect model for Agile practitioners which will be helpful in increasing productivity.

\section{REFERENCES}

[1] O. McHugh, K. Conboy, and M. Lang, "Using Agile Practices to Influence Motivation within IT Project Teams," Scand. J. Inf. Syst. (Special Issue IT Proj. Manag., vol. 23, p. pp 85-110, 2011.

[2] J. Highsmith and A. Cockburn, "Agile Software Development: The Business of Innovation," Science (80-. )., vol. 34, no. 9, pp. 120-123, 2001.

[3] C. De O. Melo, C. Santana, and F. Kon, "Developers motivation in agile teams," Proc. - 38th EUROMICRO Conf. Softw. Eng. Adv. Appl. SEAA 2012, no. March 2015, pp. 376-383, 2012.

[4] M. J. Akhtar, A. Ahsan, and W. Z. Sadiq, "Scrum adoption, acceptance and implementation (A case study of Barriers in Pakistan's IT Industry and Mandatory Improvements)," Proc. - 2010 IEEE 17th Int. Conf. Ind. Eng. Eng. Manag. IE EM2010, pp. 458-461, 2010.

[5] Colleen Frye, "Agile by the numbers: Survey finds more adoption, but age-old problems." [Online]. Available: http://searchsoftwarequality.techtarget.com/news/1372395/Agile-by-thenumbers-Survey-finds-more-adoption-but-age-old-problems. [Accessed: 24-Jul-2017].

[6] R. P. Wagener, "Investigating critical success factors in agile systems development projects/Ruhan Wagener.," no. November, 2012.

[7] T. Chow and D.-B. Cao, "A survey study of critical success factors in agile software projects," J. Syst. Softw., vol. 81, no. 6, pp. 961-971, 2008.

[8] N. Baddoo and T. Hall, "Motivators of Software Process Improvement: An analysis of practitioners' views," J. Syst. Softw., vol. 62, no. 2, pp. 85-96, 2002.

[9] Maryam, R., Naseem, A., Haseeb, J., Hameed, K., Tayyab, M., \& Shahzaad, B. (2017). Introducing Time based Competitive Advantage in IT Sector with Simulation. International Journal Of Advanced Computer Science And Applications, 8(7), 401-406.

[10] K. Petersen, R. Feldt, S. Mujtaba, and M. Mattsson, "Systematic Mapping Studies in Software Engineering," 12Th Int. Conf. Eval. Assess. Softw. Eng., vol. 17, p. 10, 2008.

[11] R. Sach, H. Sharp, and M. Petre, "Software Engineers' Perceptions of Factors in Motivation: The Work, People, Obstacles," 2011 Int. Symp. Empir. Softw. Eng. Meas., pp. 368-371, 2011. 
[12] A. C. C. Franca, D. E. S. Carneiro, and F. Q. B. da Silva, "Towards an Explanatory Theory of Motivation in Software Engineering: A Qualitative Case Study of a Small Software Company," 2012 26th Brazilian Symp. Softw. Eng., pp. 61-70, 2012.

[13] P. C. Chen, C. C. Chern, and C. Y. Chen, "Software project team characteristics and team performance: Team motivation as a moderator," in Proceedings - Asia-Pacific Software Engineering Conference, APSEC, 2012, vol. 1, pp. 565-570.

[14] C. de O. Melo, C. Santana, and F. Kon, "Developers Motivation in Agile Teams," in 2012 38th Euromicro Conference on Software Engineering and Advanced Applications, 2012, pp. 376-383.

[15] Z. Masood, R. Hoda, and K. Blincoe, "Motivation for Self-Assignment: Factors Agile Software Developers Consider," in 2017 IEEE/ACM 10th International Workshop on Cooperative and Human Aspects of Software Engineering (CHASE), 2017, pp. 92-93.

[16] O. Dieste, E. R. Fonseca C., G. Raura, and P. Rodriguez, "Professionals Are Not Superman: Failures beyond Motivation in Software Experiments," in 2017 IEEE/ACM 5th International Workshop on Conducting Empirical Studies in Industry (CESI), 2017, pp. 27-32.

[17] S. Beecham, H. Sharp, N. Baddoo, T. Hall, and H. Robinson, "Does the XP environment meet the motivational needs of the software developer? An empirical study," in AGILE 2007 (AGILE 2007), 2007, pp. 37-49.

[18] K. Conboy and S. Coyle, "People over Process : Key Challenges in Agile Development," IEEE Softw., vol. 28, no. 4, pp. 48-57, 2011.

[19] A. C. C. França, T. B. Gouveia, P. C. F. Santos, C. A. Santana, and F. Q. B. da Silva, "Motivation in software engineering: A systematic review update," 15th Annu. Conf. Eval. Assess. Softw. Eng. (EASE 2011), pp. 154-163, 2011.

[20] B. Boehm and R. Turner, "Management challenges to implementing agile processes in traditional development organizations," IEEE Softw., vol. 22, no. 5, pp. 30-39, 2005.

[21] A. Cockburn and J. Highsmith, "Agile software development: The people factor," Computer (Long. Beach. Calif)., vol. 34, no. 11, pp. 131-133, 2001.

[22] L. Layman, L. Williams, and L. Cunningham, "Motivations and measurements in an agile case study," J. Syst. Archit., vol. 52, no. 11, pp. 654-667, 2006.

[23] D. Woit and K. Bell, "Do XP customer-developer interactions impact motivation? findings from an industrial case study," Proc. 7th Int. Work. Coop. Hum. Asp. Softw. Eng. - CHASE 2014, pp. 79-86, 2014.

[24] A. Law and R. Charron, "Effects of agile practices on social factors," ACM SIGSOFT Softw. Eng. Notes, vol. 30, no. 4, p. 1, 2005.

[25] A. Deak, A Comparative Study of Testers' Motivation in Traditional and Agile Software Development. 2014.

[26] S. Seiler, B. Lent, M. Pinkowska, and M. Pinazza, "An integrated model of factors influencing project managers' motivation - Findings from a Swiss Survey,” Int. J. Proj. Manag., vol. 30, no. 1, pp. 60-72, 2012.

[27] S. Beecham, N. Baddoo, T. Hall, H. Robinson, and H. Sharp, "Motivation in Software Engineering: A systematic literature review," Information and Software Technology, vol. 50, no. 9-10. pp. 860-878, 2008.

[28] M. Kropp and A. Meier, "Agile Success Factors A qualitative study about what makes agile projects successful," no. May 2015, 2015.

[29] S. Kim, S. Hwang, and S. Song, "An Empirical Analysis on the Effects of Agile practices on Motivation and Work Performance of Software Developers," pp. 1-16, 2009.

[30] S. Misra, V. Kumar, U. Kumar, K. Fantazy, and M. Akhter, "Agile software development practices: evolution, principles, and criticisms," Int. J. Qual. Reliab. Manag., vol. 29, no. 9, pp. 972-980, 2012.

[31] A. Baird and F. J. Riggins, "Planning and Sprinting: Use of a Hybrid Project Management Methodology within a CIS Capstone Course," J. Inf. Syst. Educ., vol. 23, no. 3, pp. 243-257, 2012.

[32] O. Mchugh, K. Conoby, and M. Lang, "Motivating agile teams: A case study of teams in ireland and sweden," in 5th International Research Workshop on Information Technology Project Management (IRWITPM 2010), 2010, pp. 71-83.

[33] G. Asproni, "Motivation, Teamwork, and Agile Development," Agil. Times, vol. 4, no. 1, pp. 8-15, 2004.
[34] A. C. Nelson and C. LeRouge, "Self-esteem: Moderator between role stress fit and satisfaction and commitment?," Proc. ACM SIGCPR Conf., pp. 74-77, 2001.

[35] M. Ilyas and S. U. Khan, "Software integration in global software development: Success factors for GSD vendors," 2015 IEEE/ACIS 16th Int. Conf. Softw. Eng. Artif. Intell. Netw. Parallel/Distributed Comput. SNPD 2015 - Proc., 2015.

[36] B. Tessem and F. Maurer, "Job Satisfaction and Motivation in a Large Agile Team,” Lncs, vol. 4536, no. 5020, pp. 54-61, 2007.

[37] E. Whitworth and R. Biddle, "Motivation and Cohesion in Agile Teams," Agil. Process. Softw. Eng. Extrem. Program., pp. 62-69, 2007.

[38] M. Lindvall et al., "Empirical Findings in Agile Methods," Proc. Extrem. Program. Agil. Methods, XP/Agile Universe 2002, pp. 197-207, 2002.

[39] G. Melnik and F. Maurer, "Comparative analysis of job satisfaction in agile and non-agile software development teams," in XP'06 Proceedings of the 7th international conference on Extreme Programming and Agile Processes in Software Engineering, 2006, pp. 32-42.

[40] T. Jansson, "Motivation theory in research on agile project management: A systematic literature review," 2013.

[41] D. V Nithyanandan, "Work value as motivation among software professionals," Manag. Prudence J., vol. 1, no. 1, pp. 23-27, 2010.

[42] D. Hutchison and J. C. Mitchell, Agile Processes in Software Engineering and Extreme Programming. 1973.

[43] S. Ahmed, K. Ghayyur, S. Ahmed, and A. Razzaq, "Motivators and Demotivators of Agile Software Development : Elicitation and Analysis," vol. 8, no. 12, pp. 304-314, 2017.

[44] A. Cockburn et al., "Advanced Software Technologies for Protecting America."

[45] P. E. McMahon, "Bridging agile and traditional development methods: A project management perspective," CrossTalk, no. 5, pp. 16-20, 2004.

[46] P.-C. Chen, C.-C. Chern, and C.-Y. Chen, "Software Project Team Characteristics and Team Performance: Team Motivation as a Moderator," in 2012 19th Asia-Pacific Software Engineering Conference, 2012, pp. 565-570.

[47] A. C. C. Franca, A. C. M. L. de Araujo, and F. Q. B. da Silva, "Motivation of software engineers: A qualitative case study of a research and development organisation," in 2013 6th International Workshop on Cooperative and Human Aspects of Software Engineering (CHASE), 2013, pp. 9-16.

[48] I. de Farias, N. G. de Sa Leitao, and H. P. de Moura, "An empirical study of motivational factors for distributed software development teams," in 2017 12th Iberian Conference on Information Systems and Technologies (CISTI), 2017, pp. 1-6.

[49] A. César, C. Franca, A. de L C Felix, and F. Q. B. da Silva, "Towards an explanatory theory of motivation in software engineering: a qualitative case study of a government organization," in 16th International Conference on Evaluation \& Assessment in Software Engineering (EASE 2012), 2012, pp. 72-81.

[50] R. Sach, H. Sharp, and M. Petre, "Software Engineers' Perceptions of Factors in Motivation: The Work, People, Obstacles," in 2011 International Symposium on Empirical Software Engineering and Measurement, 2011, pp. 368-371.

[51] S. U. Gardazi, H. Khan, S. F. Gardazi, and A. A. Shahid, "Motivation in software architecture and software project management," in 2009 International Conference on Emerging Technologies, 2009, pp. 403-409.

[52] A. Alali and J. Sillito, "Motivations for collaboration in software design decision making," in 2013 6th International Workshop on Cooperative and Human Aspects of Software Engineering (CHASE), 2013, pp. 129132.

[53] T. Chintakovid, "Factors Affecting End Users' Intrinsic Motivation to Use Software," in IEEE Symposium on Visual Languages and HumanCentric Computing (VL/HCC 2007), 2007, pp. 252-253.

[54] A. C. C. Franca, T. B. Gouveia, P. C. F. Santos, C. A. Santana, and F. Q. B. da Silva, "Motivation in software engineering: a systematic review update," in 15th Annual Conference on Evaluation \& Assessment in Software Engineering (EASE 2011), 2011, pp. 154-163.

[55] A. C. C. Franca, D. E. S. Carneiro, and F. Q. B. da Silva, "Towards an Explanatory Theory of Motivation in Software Engineering: A 
Qualitative Case Study of a Small Software Company," in 2012 26th Brazilian Symposium on Software Engineering, 2012, pp. 61-70.

[56] J. Noll, M. A. Razzak, and S. Beecham, "Motivation and Autonomy in Global Software Development," in Proceedings of the 21st International Conference on Evaluation and Assessment in Software Engineering EASE'17, 2017, pp. 394-399.

[57] A. Law and R. Charron, "Effects of agile practices on social factors," ACM SIGSOFT Softw. Eng. Notes, vol. 30, p. 1, 2005.

[58] A. César, C. França, and F. Q. B. Da Silva, "Towards Understanding Motivation in Software Engineering."

[59] E. Asan and S. Bilgen, "Agile Collaborative Systems Engineering Motivation for a Novel Approach to Systems Engineering," INCOSE Int. Symp., vol. 22, no. 1, pp. 1746-1760, Jul. 2012.

[60] O. Mchugh, K. Conoby, and M. Lang, "Motivating agile teams: A case study of teams in ireland and sweden," in 5th International Research Workshop on Information Technology Project Management (IRWITPM 2010), 2010, vol. 8, pp. 71-83.

[61] a Fernando, "The Impact of Job Design and Motivation on Employee Productivity as Applicable in the Context of Sri Lankan Software Engineers : A HR Perspective," A HR Perspect., vol. 6, no. 2, pp. 67-78, 2008.

[62] D. V Nithyanandan, "WORK VALUE AS MOTIVATION AMONG SOFTWARE PROFESSIONALS."

[63] A. Deak, "A Comparative Study of Testers' Motivation in Traditional and Agile Software Development," Springer, Cham, 2014, pp. 1-16.

[64] N. Baddoo, T. Hall, and D. Jagielska, "Software developer motivation in a high maturity company: a case study," Softw. Process Improv. Pract., vol. 11, no. 3, pp. 219-228, May 2006.

[65] G. Concas, E. Damiani, M. Scotto, and G. Succi, Eds., Agile Processes in Software Engineering and Extreme Programming, vol. 4536. Berlin, Heidelberg: Springer Berlin Heidelberg, 2007.

[66] A. Elssamadisy and D. West, "Adopting agile practices: an incipient pattern language," p. 1:1-1:9, 2006.

[67] K. Schwaber, Agile Software Development with Scrum. Prentice Hall, 2004.

[68] C. Hansson, Y. Dittrich, B. Gustafsson, and S. Zarnak, "How agile are industrial software development practices?," J. Syst. Softw., vol. 79, no. 9, pp. 1295-1311, Sep. 2006.

[69] D. J. Anderson, Agile Management for Software Engineering: Applying the Theory of Constraints for Business Results. Prentice Hall Professional Technical Reference, 2004.

[70] C. H. Becker, "Using eXtreme Programming in a Student Environment," no. December, p. 135, 2010.

[71] K. Conboy, S. Coyle, X. Wang, and M. Pikkarainen, "People over process: Key challenges in agile development," IEEE Softw., vol. 28, no. 4, pp. 48-57, 2011.

[72] E. Programming, "Assessing XP at a European Internet Company," pp. $37-43,2003$.

[73] "Towards Understanding of Software Engineer Motivation in Globally Distributed Projects Research proposal," pp. 9-11.

[74] Everette R Keith -, "Agile Software Development Processes A Different Approach to Software Design."
[75] J. Drobka, D. Noftz, and Rekha Raghu, "Piloting XP on four missioncritical projects," IEEE Softw., vol. 21, no. 6, pp. 70-75, Nov. 2004.

[76] S. Misra, V. Kumar, U. Kumar, K. Fantazy, and M. Akhter, "Agile software development practices: evolution, principles, and criticisms," Int. J. Qual. Reliab. Manag., vol. 29, no. 9, pp. 972-980, Oct. 2012.

[77] M. Kropp and A. Meier, "Agile Success Factors - A qualitative study about what makes agile projects successful,” Jan. 2015.

[78] T. D. LaToza and A. van der Hoek, "Crowdsourcing in Software Engineering: Models, Motivations, and Challenges," IEEE Softw., vol. 33, no. 1, pp. 74-80, Jan. 2016.

[79] S. Beecham, H. Sharp, N. Baddoo, T. Hall, and H. Robinson, "Does the XP environment meet the motivational needs of the software developer? An empirical study," in Proceedings - AGILE 2007, 2007, pp. 37-48.

[80] A. C. C. Franca, D. E. S. Carneiro, and F. Q. B. da Silva, "Towards an Explanatory Theory of Motivation in Software Engineering: A Qualitative Case Study of a Small Software Company," in 2012 26th Brazilian Symposium on Software Engineering, 2012, pp. 61-70.

[81] A. Law, R. Charron, A. Law, and R. Charron, "Effects of agile practices on social factors," in Proceedings of the 2005 workshop on Human and social factors of software engineering - HSSE '05, 2005, vol. 30, no. 4, pp. $1-5$.

[82] S. Beecham, N. Baddoo, T. Hall, and H. Robinson, "Protocol for a Systematic Literature Review of Motivation in Software Engineering Systematic Review - Cover Sheet," Computer (Long. Beach. Calif)., no. September, p. 87, 2006.

[83] T. Jansson, "Motivation theory in research on agile project management : A systematic literature review," 2013.

[84] A. Deak, "A Comparative Study of Testers' Motivation in Traditional and Agile Software Development," Springer, Cham, 2014, pp. 1-16.

[85] O. Mchugh, K. Conboy, and M. Lang, "Using Agile Practices to Influence Motivation within IT Project Teams Using Agile Practices to Influence Motivation,” Scand. J. Inf. Syst., vol. 23, no. 2, pp. 1-26, 2011.

[86] E. Whitworth and R. Biddle, "Motivation and Cohesion in Agile Teams," in Agile Processes in Software Engineering and Extreme Programming, Berlin, Heidelberg: Springer Berlin Heidelberg, 2007, pp. 62-69.

[87] M. Dall'Agnol, A. Sillitti, and G. Succi, "Empirical Analysis on the Satisfaction of IT Employees Comparing XP Practices with Other Software Development Methodologies," Extrem. Program. Agil. Process. Softw. Eng. Proc., vol. 3092, no. June 2014, pp. 223-226, 2004.

[88] H. M. Huisman and J. Iivari, "Systems development methodology use in South Africa," Proc. 9th Am. Conf. Inf. Syst., pp. 1040-1052, 2003.

[89] C. H. Becker, "Using Extreme Programming in a Maintenance Environment," no. December, p. 135, 2010.

[90] Martin Fowler, "Writing The Agile Manifesto." [Online]. Available: https://martinfowler.com/articles/agileStory.html. [Accessed: 30-May2017].

[91] Ghayyur, S. A. K., Ahmed, S., Naseem, A., \& Razzaq, A. (2017). Motivators and Demotivators of Agile Software Development: Elicitation and Analysis. International Journal Of Advanced Computer Science And Applications, 8(12), 304-314.

[92] I. Asghar and M. Usman, "Motivational and de-motivational factors for software engineers: An empirical investigation," Proc. - 11th Int. Conf. Front. Inf. Technol. FIT 2013, pp. 66-71, 2013. 